\title{
Preventive Measures Against The Vectors Of Malaria In Akanda, Southwest Gabon: Knowledge, Attitudes, Practices, And Beliefs
}

\author{
Richard Pamba, \\ Silas Lendzele Sevidzem,
}

Ecole Doctorale des Grandes Ecole de Libreville (EDGE), Libreville, Gabon Laboratoire d'Ecologie Vectorielle (LEV), Institut de Recherche en Ecologie Tropicale (IRET), Centre National de la Recherche Scientifique et Technologique, Libreville, Gabon

Aubin Armel Koumba,

Laboratoire d'Ecologie Vectorielle (LEV), Institut de Recherche en Ecologie

Tropicale (IRET), Centre National de la Recherche Scientifique et Technologique, Libreville, Gabon

Faculté des Sciences et Techniques (FAST), Université d'Abomey-Calavi, Cotonou, Bénin

Christophe Roland Zinga-Koumba, Audrey Prisca Melodie Ovono, Rodrigue Mintsa-Nguema, Jacques François Mavoungou, Laboratoire d'Ecologie Vectorielle (LEV), Institut de Recherche en Ecologie Tropicale (IRET), Centre National de la Recherche Scientifique et Technologique, Libreville, Gabon

Alexis Mbouloungou,

Laboratoire de Géomatique, de Recherche Appliquée et de Conseil (LAGRAC), Université Omar Bongo (UOB), Faculté des Lettres et Sciences Humaines (FLSH), Libreville, Gabon

Felicien M'Foubou Kassa,

Institut d'Hygiène Publique et Assainissement, Ministère de la Santé, Libreville, Gabon

Pyazzi Obame Ondo Kutomy,

Programme National de Lutte contre le Paludisme, Ministère de la santé, Libreville, Gabon

Doi:10.19044/esj.2021.v17n21p169

Submitted: 05 August 2020

Accepted: 27 May 2021

Published: 30 June 2021
Copyright 2021 Author(s)

Under Creative Commons BY-NC-ND 4.0 OPEN ACCESS 
Cite As:

Pamba R., Sevidzem S.L., Koumba A.A., Zinga-Koumba C.R., Ovono A.P.M., MintsaNguema R., Mavoungou J.F., Mbouloungou A., M’Foubou Kassa F. \& Kutomy P.O.O. (2021). Preventive Measures Against The Vectors Of Malaria In Akanda, Southwest Gabon: Knowledge, Attitudes, Practices, And Beliefs. European Scientific Journal, ESJ, 17(21), 169. https://doi.org/10.19044/esj.2021.v17n21p169

\section{Abstract}

Background: Reliable data on the Knowledge, Attitudes, Beliefs, and Practices (KABP) of the indigenes of Akanda and its environs on the different approaches to fight against vectors of malaria is lacking. Objective: To evaluate the KABP of the indigenes of Akanda and its environs on the different techniques used to fight against vectors of malaria. Materials and Methods: A cross sectional survey using semi-structured questionnaires was conducted on heads of randomly selected households at Akanda from April to June 2019. Results: We interviewed 369 heads of households and the population had a high literacy rate. It was noticed that $94 \%$ of respondents knew that mosquitoes could transmit malaria. More than $80 \%$ believed that InsecticideTreated bed Nets (ITNs) could protect them from malaria infection. There was no preference in ITNs usage with age cohorts and seasons of the year. The ITNs owned by respondents were mostly purchased from shops. Respondents underlined that their reluctance to sleep under ITNs was because of their inability to breath under such conditions. Also, apart from the use of ITNs for malaria control, Indoor Residual Spraying (IRS) using insecticides (mostly Rambo $\left.{ }^{\circledR}\right)$ purchased from shops and cleaning around house surroundings were practiced by $>50 \%$ of respondents. Conclusion: Despite respondent's awareness of mosquitoes as vectors of malaria as well as the use of ITNs, IRS, and cleaning of home surroundings to reduce malaria vectors burden, the ITNs coverage rate is very weak and more sensitization is also required at Akanda in Gabon.

Keywords: Malaria, vectors, KABP, control, Akanda, Gabon

\section{Introduction}

Malaria remains an important parasitic disease of man despite tremendous efforts over the years to bring the infection rates to bay (Badger-Emeka, 2020). Africa remains the most affected continent with 93\% (213 millions) of global malaria burden and 94\% deaths (WHO, 2018). Besides malaria, arboviral infections such as dengue, chikungunya, yellow fever and Zika fever, threaten 831 millions people worldwide, including $70 \%$ of the African population (Zahouli et al., 2017). 
In Gabon, arthropod-borne diseases are a threat to its public health (Paupy et al., 2012; Minsanté-SNIS, 2018a; Minsanté-SNIS, 2018b). According to the National Health Information System (NHIS) of Gabon, malaria was the cause of 153666 cases of consultations and 160 deaths recorded in health care facilities in 2016 (Minsanté-SNIS, 2016). According to Leroy et al. (2009), the 2007 Chikungunya epidemic affected nearly 20,000 individuals in the country. Malaria in particular is the main scourge to economic development (due to its high mortality and morbidity rates) as well as school and professional absenteeism in Gabon (Minsanté-SNIS, 2016).

The fight against these vector-borne diseases relies on the control of vector populations (Diakarida et al., 2019 ; Beugre et al., 2020 ; Zagui et al., 2020). The major component of vector control is through the use of insecticides that are applied via different modes (Sevidzem et al., 2019). In the case of mosquitoes, The different modes of insecticide application include insecticide-treated bed nets (ITNs or LLINs), and Indoor Residual Spraying (IRS) (Nd'ri et al., 2020).

The malaria control program of the Ministry of health in Gabon is the only public organ responsible for the fight against malaria and its vectors and has been involved in mass control programs such as distribution of insecticide bed nets and sensitizations. At the community level, indoor residual spraying is common and most of these insecticides are purchased from local vendors (Nd'ri et al., 2020). In 2018, Koumba et al. (2018) established the occurrence of resistant alleles (kdr-w and kdr-e) in a rural community of Gabon and attributed this to insecticide resistance selection pressure caused by the repeated usage of some non-standard insecticides. Because the community of Akanda was reported to have high malaria vector abundance and malaria prevalence (Pamba et al., 2020a; Pamba et al., 2020b), it was deemed necessary to conduct a survey to evaluate the knowledge, attitudes, practices, and beliefs of the population of Akanda on the fight against the vectors of malaria in order to provide reliable data required by malaria control program of Gabon.

\section{Materials and Methods Study area}

This study was conducted in the city of Akanda $\left(0^{\circ} 30^{\prime} 00^{\prime \prime}\right.$ North; $09^{\circ} 30^{\prime} 00^{\prime \prime}$ East) (Figure 1), a suburban area located in the northern periphery of the city of Libreville, the capital of Gabon. Akanda covers 45482 hectares of land and is part of the departement du Komo-Mondah in the province de l'Estuaire.

There are several socio-economic activities including trading, sports, health, education, and tourism in this locality. Entomologically, the study of Pamba et al. (2020a) identified several breeding sites as well as adults of the 
vectors of malaria and arboviruses in Akanda. A hospital-based survey indicated that Akanda is a malaria endemic zone (Pamba et al., 2020b).

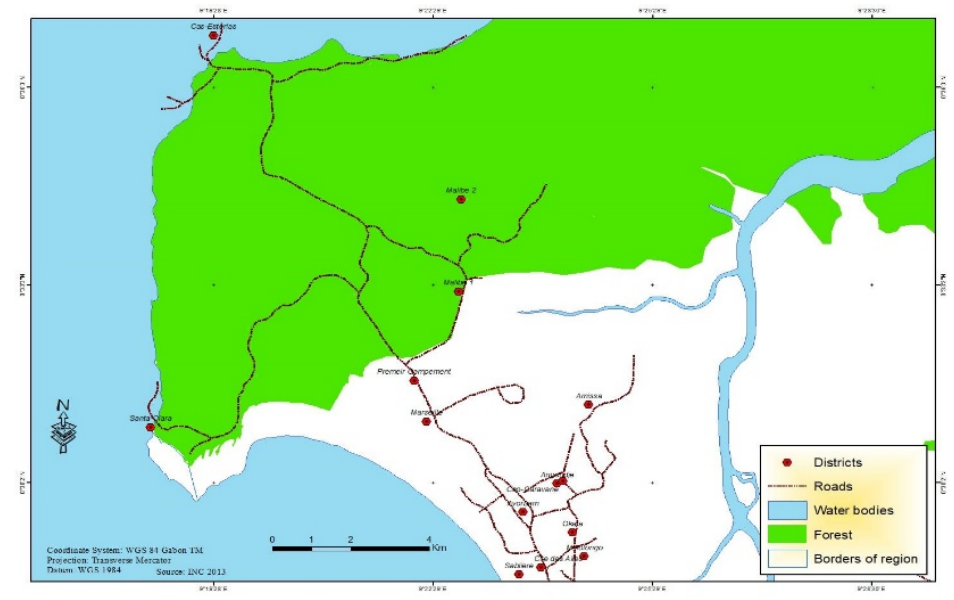

Figure 1. Map showing the study area (Akanda) and its districts

\section{Ethics}

Oral consent was received from the target population before commencing the study.

\section{Cross-sectional survey}

Three hundred and sixty nine (369) heads of households residing in Akanda and its environs were randomly selected and included in the study.

\section{Data analysis}

Data analysis was conducted using Sphinx Plus $^{2}$ version 5.0. Descriptive statistics (frequencies and percentages) were calculated.

\section{Results}

\section{Description of respondents}

A total of 369 heads of households were interviewed and consisted of 187 males and 182 females. The age cohort that was most highly represented was from 20-29 years old. Concerning the level of education, most of the respondents had completed secondary school. Based on the housing type, most of the buildings of respondents were constructed with cement blocks (Table $1)$.

Table 1. Socio-demographic information of the study population

\begin{tabular}{|c|c|c|c|}
\hline Parameters & Category & Number & Proportion (\%) \\
\hline Sex & Male & 187 & 50.68 \\
\hline & Female & 182 & 49.32 \\
\hline Age & $15-19$ & 27 & 7.32 \\
\hline
\end{tabular}




\begin{tabular}{|c|c|c|c|}
\hline & $20-29$ & 119 & 32.25 \\
\hline & $30-39$ & 92 & 24.93 \\
\hline & $40-49$ & 85 & 23.04 \\
\hline & $>50$ & 46 & 12.47 \\
\hline Level of education & No response & 1 & 0.27 \\
\hline & Never been to school & 34 & 9.21 \\
\hline & Primary & 37 & 10.03 \\
\hline & Secondary & 144 & 39.02 \\
\hline & Professional school & 61 & 16.53 \\
\hline & University & 92 & 24.93 \\
\hline Housing type & Cement blocks & 249 & 67.48 \\
\hline & Wood & 90 & 24.39 \\
\hline & Soil bricks & 30 & 6.78 \\
\hline
\end{tabular}

\section{Respondents knowledge on malaria}

A majority (94\%) of the respondents attributed malaria to bites from infected mosquitoes. Only 6\% had erroneous knowledge on the cause of malaria (Figure 2).

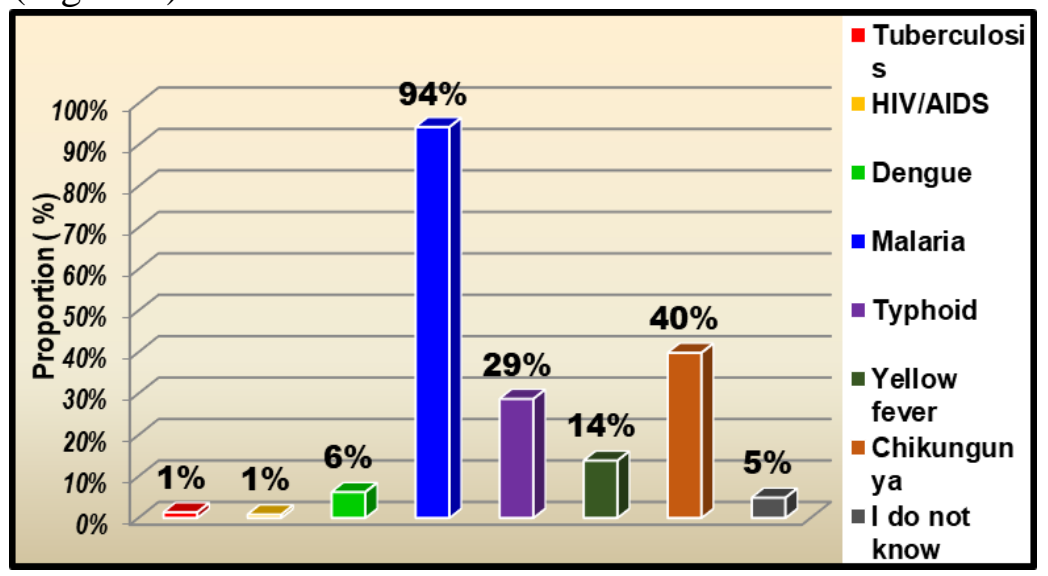

Figure 2. Knowledge of respondents on mosquito as vector of malaria

\section{Respondents knowledge on the different mosquito control approaches}

More than eighty percent ( $80 \%$ ) of respondents were aware of the use of insecticide-treated bed nets (ITNs/LLINS) to control malaria. More than $60 \%$ of the respondents cleaned around their households to kill mosquitoes (Table 2). The most frequently used insecticide for Indoor Residual Spraying (IRS) to kill mosquitoes was Rambo ${ }^{\circledR}(62.06 \%)$ and Raid ${ }^{\circledR}$ was rarely used (Table 2).

Table 2. Knowledge of respondents on the fight against malaria vectors

\begin{tabular}{|c|c|c|c|}
\hline Parameter & Category & Number & $\begin{array}{c}\text { Proportion } \\
(\%)\end{array}$ \\
\hline
\end{tabular}




\begin{tabular}{|c|c|c|c|}
\hline $\begin{array}{c}\text { Which method(s) you know is used } \\
\text { to fight against mosquitoes }\end{array}$ & No response & 1 & 0.27 \\
\hline & Fan & 112 & 30.35 \\
\hline & Vaccination & 48 & 13.01 \\
\hline & Mosquito & 186 & 50.41 \\
\hline & Mosquito nets & 301 & 81.57 \\
\hline & Insecticide & 193 & 52.30 \\
\hline & $\begin{array}{c}\text { Air } \\
\text { conditioner }\end{array}$ & 19 & 5.15 \\
\hline & $\begin{array}{c}\text { Cleaning } \\
\text { around } \\
\text { homestead }\end{array}$ & 243 & 65.85 \\
\hline & Others & 16 & 4.34 \\
\hline Types of insecticide brands used to & No response & 2 & 0.54 \\
\hline kill mosquitoes & None & 89 & 24.12 \\
\hline & Rambo $^{\circledR}$ & 229 & 62.06 \\
\hline & ORO $^{\circledR}$ & 26 & 7.05 \\
\hline & Killit $^{\circledR}$ & 30 & 8.13 \\
\hline & Killtox $^{\circledR}$ & 4 & 1.08 \\
\hline & Raid & \\
\hline & Others $^{\circledR}$ & 1 & 0.27 \\
\hline & & 64 & 17.34 \\
\hline
\end{tabular}

\section{Respondents knowledge, attitudes, Practices, and Beliefs on insecticide- treated bed nets}

A high proportion of the respondents used insecticide-treated bed nets to prevent the bites of mosquitoes. Most respondents (82.66\%) stated that children as well as adults slept under ITNs. A high number of respondents stated that they used ITNs was all year round. We noted that some respondents did not choose to sleep under ITNs because of the difficulty breathing under such conditions (Table 3).

Table 3. Respondents knowledge, attitudes, practices, and beliefs on the use of insecticidetreated bed nets

\begin{tabular}{|c|c|c|c|}
\hline Parameters & Category & Number & Proportion (\%) \\
\hline $\begin{array}{c}\text { Do you use mosquito } \\
\text { nets? }\end{array}$ & No response & 227 & 61.52 \\
\hline & Yes & 105 & 28.46 \\
\hline $\begin{array}{c}\text { Reasons why you do not } \\
\text { use mosquito bed nets }\end{array}$ & No response & 37 & 10.03 \\
\hline & Negligence & 11 & 88.89 \\
\hline & Difficult to use & 3 & 2.98 \\
\hline & $\begin{array}{c}\text { I feel heat when sleeping under } \\
\text { mosquito bed net }\end{array}$ & 9 & 2.41 \\
\hline
\end{tabular}




\begin{tabular}{|c|c|c|c|}
\hline & $\begin{array}{c}\text { Difficulty breathing when sleeping } \\
\text { under mosquito bed net }\end{array}$ & 16 & 4.34 \\
\hline & It disturbs me from sleeping & 4 & 1.08 \\
\hline & Others & 5 & 1.36 \\
\hline $\begin{array}{c}\text { Persons sleeping under } \\
\text { mosquito bed nets }\end{array}$ & No response & 227 & 61.52 \\
\hline & $\begin{array}{c}\text { No body sleeps under mosquito bed } \\
\text { nets }\end{array}$ & 21 & 5.69 \\
\hline & Children between 0 to 5 years old & 30 & 8.13 \\
\hline & Children and adults & 99 & 26.83 \\
\hline & Pregnant women & 3 & 0.81 \\
\hline $\begin{array}{c}\text { Which period of the year } \\
\text { do you use mosquito bed } \\
\text { nets? }\end{array}$ & No response & 1 & 0.27 \\
\hline & Dry season & 8 & 2.17 \\
\hline & Rainy season & 41 & 11.11 \\
\hline & Throughout the year & 305 & 82.66 \\
\hline & I do not know & 14 & 3.79 \\
\hline
\end{tabular}

It was observed that most of the respondents purchased their ITNs from shops (Table 4). Some that received free ITNs said it was from family members, friends, etc. In Gabon, the price of a mosquito net ranges from 3500 to 8000 FCFA.

Table 4. Source of acquisition of mosquito bed nets

\begin{tabular}{|c|c|c|c|}
\hline Parameter & Category & Number & Proportion (\%) \\
\hline $\begin{array}{c}\text { Mode of aquisition of } \\
\text { mosquito nets }\end{array}$ & No response & 228 & 61.79 \\
\hline & Purchase & 106 & 28.73 \\
\hline & Free & 40 & 10.84 \\
\hline
\end{tabular}

\section{Discussion}

Results from surveys on knowledge, attitudes, beliefs and practices are applicable to design or improve malaria control programs, and to identify indicators for a program's effectiveness (Mazigo et al., 2010). The result of our study can be incorporated into the decision-making processes, the design of sustainable interventions with active community participation, and the implementation of sensitization schemes in Gabon. The study population consisted of literate adults who were able to understand our research questions.

About $94 \%$ of the respondents were aware that mosquito bites could lead to the transmission of malaria. This observation has also been made in Nigerian communities by Enato et al. (2007) and those in Côte d'Ivoire by N'di et al. (2020). We noted that in addition to the usage of ITNs, respondents (60\%) also cleaned around their buildings to destroy the breeding sites of mosquitoes. This practice of respondents fits perfectly with scientific findings 
of Pamba et al. (2020a) who reported that abandoned containers as well as natural substrates constituted mosquito breeding sites in Akanda.

Indoor Residual Spraying (IRS) was equally practiced by more than $50 \%$ of the respondents. However, the insecticide that was mostly used for the IRS was Rambo ${ }^{\circledR}$ and this could be explained by the fact that it is cheap and available in shops (Mbouloungou et al., 2020). We found that more than $80 \%$ of the respondents were aware that the use of ITNs could prevent malaria. This observation has been made by N'dri et al. (2020) and Jumbam et al. (2020). However, only The respondents reluctance to sleep under ITNs was because it impaired breathing and generated heat. This observation has been made in a similar survey in Angola by Foumane et al. (2015) and in Ghana by Owusu et al. (2018).

Also, most respondents allowed children and adults to sleep under ITNs and this practice has been observed elsewhere by different authors (Owusu et al., 2018 ; Jumbam et al., 2020).

Most respondents used ITNs throughout the year and this could be due to the annual aggressivity pattern of mosquitoes that makes them use this approach all the time. This observation corroborated the finding of MaghendjiNzondo et al. (2016) and Mbouloungou et al. (2019) that malaria cases occurred throughout the year with peak in the short rainy season. We found that most respondents purchased ITNs themselves and only few individuals were provided to them free. Because most individuals prefer to use ITNs donated for free than to purchase, this could explain the low percentage of those who use ITNs to fight malaria in Akanda and its environs.

\section{Conclusion}

We noticed that $94 \%$ of the respondents were aware of the fact that malaria is transmitted by mosquitoes. More than $80 \%$ of them believed that ITNs could prevent malaria infection. However, only $28.5 \%$ of respondents reported using ITNs. The use of Indoor Residual Spray (IRS) and cleaning around houses was also practiced. There was no preference in ITNs usage by age cohort or season of the year. The ITNs used by most respondents were purchased. This preliminary finding on the KABP of the indigenes of Akanda and its environs on the use of malaria preventive measures will instruct the malaria control program of Gabon to prepare and execute effective control approaches for this part of the country.

\section{Acknowledgements}

Authors thank Merly Trevis Koumba, Darlie Ruth G. ManombaKoumba and Anastasie Kengue for their technical support during the questionnaire survey. 


\section{References:}

1. Badger-Emeka, L. I. (2020). The malaria burden : a look at 3 years outpatient malaria clinic visits in a University community town in Southeast Nigeria. Nigerian Journal of Clinical Practice, 23(5): 711719.

2. Beugré, J. M. V., Yao-Acapovi, G. L., Fofana, D., Koné, A. B., Konan, K. L. \& Sevidzem, S. L. (2020). Breeding substrates and diversity of Aedes species in Peri-urban areas of Côte d'Ivoire. International Journal of Mosquito Research, 7(4): 39-44.

1. Diakarida, F., Jean, M. V. B., Yao-Acapovi, G. L. \& Sevidzem, S. L. (2019). Risk of Dengue Transmission in Cocody (Abidjan, Ivory Coast). Journal of Parasitological Research, 1: 1-7 https://doi.org/10.1155/2019/4914137.

2. Enato, E. F., Augustine O., Okhamafe, O., Eugene, E. \& Okpere, E. (2007). A survey of knowledge, attitude and practice of malaria management among pregnant women from two health care facilities in Nigeria. Acta Obstetricia et Gynecologica, 86: 33-36.

3. Foumane, V., Besnard, P., Le Mire, J., Fortes, F., Dos Santos, M., Carnevale, P. \& Manguin, S. (2015). First Knowledge, Attitude and Practices (KAP) Survey of Mosquitoes and Malaria Vector Control at Household Level in Lobito Town (Angola). Infectious Diseases \& Therapy, 3: 4. http://dx.doi.org/10.4172/2332-0877.1000230.

4. Jumbam, D. T., Stevenson, J. C., Matoba J., Grieco, J. P., Ahern, L. N., Hamainza, B, Sikaala, C. H., Chanda-Kapata, P., Esther, I. C., Passwell, M. \& Nicole, L. A. (2020). Knowledge, attitudes and practices assessment of malaria interventions in rural Zambia. Public Health, 20: 216 https:/doi.org/10.1186/s12889-020-8235-6.

5. Koumba, A. A., Zinga Koumba, C. R., Mintsa Nguema, R., Obame Ondo, P., Akono Ntonga, P., Sevidzem, S. L., Ketoh, G. K., Djogbenou, L. S., Mavoungou, J. F. (2018). Identification of the kdr resistance genes in Anopheles gambiae s.l. in the Mouila area, Southwest Gabon. Journal of Entomology and Zoology Studies, 6(3) : 602-607.

6. Leroy, E. M., Nkoghe, D., Ollomo, B., Nze-Nkoghe, C., Becquart, P., Grard, G., Pourrut, X., Charrel, R., Moureau, G., Ndjoyi-Mbiguino, A. \& De Lamballerie, X. (2009). Concurrent Chikungunya and Dengue virus infections during simultaneous outbreaks, Gabon, 2007. Emerging Infectious Diseases, 15(4) : 591-593.

7. Maghendji-Nzondo, S., Nzoughe, H., Lemamy, G. J., Kouna, L. C., Pegha-Moukandja, I., Lekoulou, F., Mbatchi, B., Toure-Ndouo, F. \& Lekana-Douki, J. B. (2016). Prevalence of malaria, prevention 
measures, and main clinical features in febrile children admitted to the Franceville Regional Hospital, Gabon. Parasite, 23(32): 1-9.

8. Mathania, M. M., Kimera, S. I. \& Silayo, R. S. (2016). Knowledge and awareness of malaria and mosquito biting behaviour in selected sites within Morogoro and Dodoma regions Tanzania. Malaria Journal, 15 : 287. DOI 10.1186/s12936-016-1332-4.

9. Mazigo, H. D., Obasy, E., Mauka, W., Manyiri, P., Zinga, M., Kweka, E. J., Mnyone, L. L. \& Heukelbach, J. (2010). Knowledge, Attitudes, and Practices about Malaria and Its Control in Rural Northwest Tanzania. Malaria Research and Treatment, 9p. doi:10.4061/2010/794261.

10. Mbouloungou, A., Koumba, A. A., Mombo, J. B., Ndonghan Iyangui, N., Mavoungou, J. F. \& Djeki, J. (2019). Géographie du paludisme dans la région de Libreville-Owendo-Akanda, Gabon. European Scientific Journal, 15(2) : 362-382.

11. Mbouloungou, A., Koumba, A. A., Pamba, R., Zinga Koumba, C. R., Djeki, J., Mombo, J. B. \& Mavoungou, J. F. (2020). Utilisation des Insecticides Anti-Moustiques et Risques pour la Santé dans la Région de Libreville et ses Environs (Gabon). International Journal of Progressive Sciences and Technologies, 19(1): 52-64.

12. Minsanté-SNIS (2018a). Annuaire statistique année 2017. Ministère de la Santé de la République Gabonaise. Libreville, Gabon, 337p.

13. Minsanté-SNIS (2018b). Carte sanitaire 2017. Ministère de la Santé de la République Gabonaise. Libreville, Gabon, 215p.

14. Minsanté-SNIS (2016). Mission de collecte des donnés en vue d'une cartographie pour établir un état des lieux, des équipements, des usages et perception des TIC des établissements concernés par le Système National d'Information Sanitaire (SNIS). Rapport final de mission, Libreville, 139p.

15. N’Dri, B. P., Heitz-Tokpa, K., Chouaïbou, M., Raso, G., Koffi, A. J., Coulibaly, J. T., Yapi, R. B., Müller, P. \& Utzinger, J. (2020). Use of Insecticides in Agriculture and the Prevention of Vector-Borne Diseases: Population Knowledge, Attitudes, Practices and Beliefs in Elibou, South Côte d'Ivoire. Tropical Medicine and Infectious Diseases, 5 : 36. doi:10.3390/tropicalmed5010036 www.

16. Owusu, E. D. A., Cremers, A. L., Brown, C. A., Mensa, P. F. \& Grobusch, M. P. (2018). Knowledge, attitudes and practices regarding malaria in people living with HIV in rural and urban Ghana. Acta Tropica, $181:$ 16-20.

17. Pamba, R., Koumba, A. A., Zinga-Koumba, C. R., Sevidzem, S. L., Mbouloungou, A., Yacka, L. L., Djogbenou, L. S., Mavoungou, J. F. \& M'Batchi, B. (2020a). Typology of Breeding Sites and Species 
Diversity of Culicids (Diptera: Culicidae) in Akanda and its Environs (North West, Gabon). European Journal of Biology and Biotechnology, 1(1) : 1-6. DOI: http://dx.doi.org/10.24018/ejbio.2020.1.1.13.

18. Pamba, R., Koumba, A. A., Zinga Koumba, C. R., Ovono, A. P. M., Itsiembou, L. D., Ogouliguende, S. T., Obame Ondo, P., Sevidzem, S. L., Mintsa-Nguema, R. \& Mavoungou, J. F. (2020b). Microbes and Infectious Diseases., doi: 10.21608/MID.2020.106314.

19. Paupy, C., Kassa Kassa, F., Caron, M., Nkoghe, D. \& Leroy, E. M. (2012). A chikungunya outbreak associated with the vector Aedes albopictus in remote villages of Gabon. Vector Borne Zoonotic Diseases, 12 : 167-169.

20. Sevidzem, S. L., Tchawe, R., Zinga-Koumba, R., Mamoudou, A., Ndjonka, D., \& Mavoungou, J. F. (2019). Insecticide coated screen models reduce insect-vector population in a pasture area in Ngaoundere, Cameroon. Trends Applied Sci. Res., 14: 80-89.

21. WHO (2018). The World Malaria Report 2018. World Health Organization, Geneva, 210p.

22. Zagui, D. W. G., Fofana, D., Koné, A. B., Konan, K. L., Beugré, J. M. V., Sevidzem, S. L. \& Yao-Acapovi, G. L. (2020). Impact of integrated fight against vectors of arboviruses on the epidemic risk indices in six communities of Abidjan, Côte d'ivoire. Journal of Entomology and Zoology Studies, 8(4): 33-36.

23. Zahouli, B. J. Z. (2017). Anthropogenic impacts on Aedes mosquitoes community dynamics in Côte d'Ivoire. Ph.D. dissertation, University of Basel, Switzerland, 173p. 